\title{
Black Mayors in Non-Majority Black (Medium-Sized) Cities: Universalizing the Interests of Blacks ${ }^{1}$
}

\author{
Ravi K. Perry, Ph.D. \\ Clark University
}

\section{Introduction}

The nature of political representation of Black constituents' interests from their elected Black representatives is changing in the twentyfirst century. Increasingly, African Americans are being elected to political offices where the majority of their constituents are not African American. Previous research on this question tended to characterize Black politicians' efforts to represent their Black constituents' interests in two frames: deracialized or racialized (McCormick and Jones 1993; Cruse 1990). However, the advent of the twenty-first century has exhausted the utility of that polarization. Black politicians no longer find explicit racial appeals appropriate for their electoral goals, given the changing demographic environment, and greater acceptance of African American politicians in highprofile positions of power. Black politicians also increasingly find that a lack of attention to racial disparities facing constituents within their political boundaries does not effectively address why certain groups like Blacks are disproportionately and negatively affected 


\section{Ethnic Studies Review Volume 32.1}

than others, across a range of issues. Rather than continue to make efforts to represent Black interests within those two frames, Black politicians have begun to universalize the interests of Blacks.

Universalizing Black interests as interests that matter for the good of the whole is increasingly the adopted governing strategy of twenty-first century African American politicians elected to offices where the majority of their constituents are not Black. As a result of the greater acceptance of African American politicians in high-profile political offices and changing demographics over the course of two decades, this new approach has been made available to Black politicians who wish to represent Black interests even given their White constituent majority - the emergence of the universalizing of Black interests as interests that matter to all constituents. This is a departure from previous approaches that advocate issues that transcend and de-emphasize race (McCormick and Jones 1993).

Universalizing the interests of Blacks, as many Black politicians have done since the turn of the century, though controversial, is a unique approach many such politicians employ to represent the interests of African Americans, without alienating support from the majority of their constituents. Universalizing the interests of Blacks in a Black politician's attempt to represent their interests is different from deracialization. It is unique in that these Black politicians, in their representation of Black interests, have often noted, for example, the racial disparities present, given the issue they support. This approach, while resulting in varying electoral levels of success for some Black politicians, has a particular benefit to a Black politician's successful governing. Had, for example, these politicians employed a deracialization strategy, they, by definition, would have not emphasized race.

McCormick and Jones define deracialization as "conducting a campaign in a stylistic fashion that defuses the polarizing effects of race by avoiding explicit reference to race-specific issues" (1993, 76). While the working definition of deracialization is limited to an electoral strategy, its application to a Black politician's governing strategy is not too far-fetched. One could replace the 'conducting a campaign' phrase with 'governing an administration,' for example, 


\section{Perry-Black Mayors in Non-Majority (Medium-Sized) Cities}

and receive a similar result. If this understanding is accepted, then it can be argued that many Black politicians no longer 'avoid explicit reference to race-specific issues.' Rather, in their attempt to represent Black interests, Black politicians increasingly note of racial disparities where appropriate and craft their rhetoric in a stylistic fashion that warrants non-Blacks not to feel threatened.

Yet, McCormick and Jones also note that a deracialized approach "at the same time emphas[izes] those issues that are perceived as racial transcendent." 1 While the McCormick and Jones definition emphasizes the avoidance of race specific issues and the advocacy of issues that transcend race, the definition does so with the underlying assumption that the topic of race is not discussed. The entire effort, then, is made on the part of the Black politician to "enhance effectively the likelihood of white electoral support" to maintain or capture public office. ${ }^{2}$ The main difference in the approach of Black politicians in the twenty-first century is often the reason behind the approach. The effort is not solely being made to win public office and gain the necessary White votes. Rather, the approach is consciously designed to represent Black interests given the majority White constituency (Ford 2009).

Some of the components of deracialization are undoubtedly present in the approach to universalize Black interests. For example, in what scholar J.Q. Wilson calls a nonthreatening image (1980, 214-254); McCormick and Jones emphasize the need for Black politicians to project a safe portrayal to Whites to obtain a greater likelihood of winning White support. However, given the greater acceptance of African Americans to high-profile political offices, the meaning of a nonthreatening image has changed since the McCormick and Jones writing. Thus, while Black politicians, who, in the twenty-first century, may make efforts to represent Black interests and do not wish to lose the support of some Whites, they often do have the support of liberal Whites in their efforts (Cunnigen 2006; Nelson 2006). Hence, projecting a nonthreatening image toward all Whites is not a concern of many Black mayors. Rather, the electoral concern has shifted to how can Black politicians

1 Ibid.

2 lbid. 


\section{Ethnic Studies Review Volume 32.1}

represent Black interests and convince enough Whites that those interests are not represented at the expense of their interests.

Corroborating this trend has been an array of elections of African American mayors of non-majority Black cities. For example, in the state of Ohio, Columbus, Toledo, Dayton, Cincinnati, Youngstown, and Cleveland all elected Black mayors in the twenty-first century. Outside of Ohio, many major cities with a history of Black mayors continued to elect them, such as, Washington, D.C., Atlanta, Georgia, New Orleans, Louisiana, and Baltimore, Maryland. Other cities with less of a history of Black mayors, elected some as well, Buffalo, New York, Tallahassee, Florida, Philadelphia, Mississippi, and Mobile, Alabama. This trend suggests Whites have an increasing willingness to vote for Black candidates when they feel as though their interests are not threatened (Hajnal 2007, 160). In other words, when African American mayors are perceived as pursuing the interests of the majority and not the interests of particular racial constituencies, (e.g., Blacks) Whites are more likely to support them in the voting booth.

Noticeably, this development excludes mention of the interests of the mayor. For example, for a reasonable number of cases, significant scholarship has not yet identified if Black mayors who garnered large amounts of White support in their election pursuits by utilizing a deracialization strategy, continued to pursue the interests of the majority, once elected. To the extent that scholars have found Black mayors do, a behavioral/psychological political analysis has yet to demonstrate if they did so preferentially. This matters because it addresses the role shared racial experience plays when Black mayors consider activities to represent the interests of African Americans in non-majority Black cities.

An attempt to introduce these and related questions, this article analyzes the question of how, if at all, the representation of Black interests is being pursued by Black mayors. Specifically, I seek to briefly examine and identify under what conditions do the elected Black mayors of non-majority Black medium-sized cities actively pursue policies and programs designed to improve the quality of life of Black residents. ${ }^{3}$ This research question is derived from two

3 It is important to acknowledge that 'active pursuit' does not equal influence or 
propositions. First, as a racial minority that has long been socially, politically and economically marginalized, Blacks historically have experienced disproportionate disparities in housing, education, and income. As a result, the election of a Black mayor is viewed by Black residents as an opportunity to see city government work in their interests and to address these inequities. Consequently, African Americans embrace the election of one of their own with high expectations.

\section{High Expectations}

When the first wave of Black mayors won office in the 1960s and 1970s, expectations ran high. Scholars who have studied former mayors Carl Stokes, Richard Hatcher, Kenneth Gibson, David Dinkins and others have noted that reality (Moore 2002; Lane 2001; Curvin 1972; Biles 2001; Thompson 2006; Reed 1999; Nelson 2006; Preston 1990). Hence, across the country, the election of Black mayors raised the expectations of Black voters. African-American voters viewed Black mayors as modern-day Messiahs who, once in office, would dramatically alter the Black community's social and economic predicaments. As Maynard Jackson, Atlanta, Georgia's first Black mayor, commented, "The level of expectations of black people when a black mayor is elected is so intensely emotional until it is almost exaggerated. It may be impossible for any human being to satisfy the level of expectations" (Bayor 2001, 181). In short, and as Nelson and Meranto $(1977,339)$ concluded, "The election of a black man as mayor of a major American city builds up extraordinarily high expectations from his black constituents." The advent of the twenty-first century has found those expectations to remain constant (McLin 2008; Ford 2008).

necessarily tell us about the outcomes. Nevertheless, evidence of 'active pursuit' will provide insight into how active Black mayors are in the governing process inside their administrations and on which issues. Furthermore, an examination of differences in mayors' actions in terms of levels of active pursuit given unique governmental structures will provide new evidence about Black mayors' policy and programmatic priorities on issues relevant to their Black residents. In addition, it will help to provide a more thorough understanding of mayoral constraints and how Blacks' interests are represented in non-majority Black urban contexts. 


\section{Demographic Trends}

The article's second proposition derived from the research question is based on population trends. Demographic changes in many American cities are steadily reversing the population dynamics that brought about the election of this nation's first African-American mayors. The 2000 U.S. Census indicates that major cities are losing Black population, while gaining Latinos and Whites (Frey 2006; Brookings 2001; Frasure 2007). Washington, D.C., Los Angeles, California, San Francisco, California, Seattle, Washington, New Orleans, Louisiana, Atlanta, Georgia, and Newark, New Jersey are examples of cities with significant declines in Black populations. ${ }^{4}$ Some of these cities, Washington, D.C., for example, have been governed by Black mayors for decades. However, should this trend continue, ambitious Black politicians will increasingly find themselves running for the office of mayor in cities which do not comprise a majority of African Americans.

\section{Theoretical Expectations}

Shared Racial Experience

The primary expectation guiding this research is that Black mayors will be involved in actively pursuing Black interest issues. This expectation is founded in scholarship on Black representation in other political contexts. In the congressional literature, there are several factors that have been shown to influence members' personal policy interests (Hall 1996). For example, despite 4 "Gentrification Changing Face of New Atlanta," New York Times, March 11, 2006; "New York City Losing Blacks, Census Shows," New York Times, April 3, 2006; "Blacks Say Life in Los Angeles Is Losing Allure," New York Times, January 8, 1995; "The Census Shows Growth in Atlanta's Population," New York Times, March 21, 2001; "Atlanta Mayor: Shrinking Black Population Court Hurt Social Policies," Cox News Service, June 2, 2007; “D.C. May Be Losing Status As a Majority-Black City; Washington Post, May 17, 2007; "San Francisco Hopes to Reverse Black Flight," USA Today, August 26, 2007; "Central District: Change Is Inevitable, But Forsaking Past is Regrettable," Seattle Times, November 6, 2002; "Study: New Orleans Could Lose 80 Percent of Black Population," Associated Press, January 26, 2006; "Major Cities Rapidly Losing Black Population: Could Have Major Negative Impact on Black Political Power," Taylor Media Services, September 25, 2007; "Black or African American Population: 1990-2000 New Jersey Municipalities" Accessed via

http://www.wnjpin.state.nj.us/OneStopCareerCenter/LaborMarketInformation/ Imi25/pl94/cnty/black.PDF. Retrieved 2009-06-20 


\section{Perry-Black Mayors in Non-Majority (Medium-Sized) Cities}

increased diversity in the Black community, Black members of Congress share the experience of being a member of a historically marginalized group (Williams 1998) and Blacks generally (Black mayors included) have a shared memory of oppression (Williams 1998, 192). Therefore, it is expected that shared history of racialized experiences will manifest in Black mayors' policy and programmatic efforts and incline Black mayors to have a personal interest in actively pursuing policies and programs that are designed to improve the quality of life of Black residents. ${ }^{5}$

Finally, the congressional literature provides another cue as to why it is expected that Black mayors will actively pursue Black interests in non-majority Black cities. For example, Gamble (2007) notes how many Black congressional members nationwide carry a heavy burden as they are often expected to represent not only their districts, but also "black America" (Clay 1992; Guinier 1994, 47). Additionally, Fenno $(2003,7)$ found that African American members of Congress often perceive their Black constituency extending beyond their geographical districts, to include Blacks nationwide, what some scholars have labeled surrogate representation. Arguably, the same may be true for Black mayors, especially those in the high-profile role of being the first Black mayor of their city. Hence, the confluence of life experience, feeling of connectedness to the group 'African American,' and commitment to represent Black interests, even within patterns of surrogate representation, makes Black mayors more likely to have strong personal interest in representing Black interests.

\section{Critics of Shared Racial Experience}

The argument for utilizing the assumption of shared racial experience as a basis to predict Black politicians' behavior has its critics. Gamble (2007) found that "theories that focus on shared experience ignore individual differences and the multiple and cross-cutting identities among members of marginalized groups,

5 Additionally supportive scholarship suggests that African American mayors might actively pursue Black interest policies in non-majority Black cities because of their feeling of connectedness to other African Americans (Dawson 1994). Other research has found that many Blacks have that connection because of social, political, and economic differences between themselves and Whites (Tate 1993, 21-29). 


\section{Ethnic Studies Review Volume 32.1}

locking group members into essentialized identities and fixed policy perspectives" (Phillips 1995). Additionally, some urban scholars have argued that contemporary Black mayors face more challenges than Black mayors first elected in major cities (Nelson 2006). Hence, even with shared experience and history, Black mayors, faced with greater challenges and a majority White electorate may not be willing or able to actively pursue Black interests.

\section{Medium-Sized Cities}

This research briefly examines select cities in the United States that are medium-sized and applies the representative efforts by Blacks mayors to universalize the interests of Blacks within that context. With the exception of few scholars (e.g., Bowers and Rich 2000), urbanists have long ignored the public policy impact of Black mayors in medium-sized cities, especially as it relates to their representation of Black interests. Yet according to the U.S. Census Bureau, many Americans live in medium-sized cities, cities with a population of less than 500,000:

\section{City Populations in the United States}

\begin{tabular}{|l|l|}
\hline Number of Cities & Population Bracket \\
\hline 263 & Over 100,000 \\
\hline 228 & $100,000-500,000$ \\
\hline 203 & $100,000-300,000$ \\
\hline 60 & $300,000-8$ million \\
\hline
\end{tabular}

Thus, limiting studies of Black mayoral governance to cities of 500,000 or more ignores generalizability for many in the population who live in cities of 100,000 or more.

Although, medium-sized cities are not often studied in urban politics, their study may help predict mayoral action given trends in other cities. To date, scholarship that has focused on mayors of medium-sized cities, has examined their leadership styles generally (Svara 1987, 1990, 1994), the impact on Black social change over time (Button 1989), or leadership in respect to a specific issue (Bowers and Rich, Eds., 2000). ${ }^{6}$ While the authors take great skill in

6 Peter Burns' Electoral Politics Is Not Enough (2006) surveys the responsiveness of medium-sized city governments to minority interests. While the focus is on 
structuring rigorous research that explains the stylistic approaches, structural conditions, and singular issue responsiveness over time under which the mayors win elections and govern, omitted is a detailed analysis of responsiveness to the concerns and issues of Blacks' quality of life.

This is increasingly significant as Black mayors govern cities that are the size of cities in which most of the world's urban population resides. The Department of Economic and Social Affairs of the United Nations Secretariat World Population Prospects 2005 Revision found that, "almost half of humanity lives in cities" and "small cities, that is, those with a population of fewer than 500,000 people, were the place of residence of about fifty-one percent of all urban dwellers in the world in 2005. Thus, the majority of urban dwellers lived in fairly small urban settlements." ${ }^{17}$ Their 2006 revision was even more compelling - projecting that by 2030, eighty-seven percent of residents of the United States will be urban dwellers. Currently, in the United States, nearly fifty percent live in small and medium-sized cities. Therefore, the actions of mayors who govern within these city contexts arguably have relevance to a larger number of people than studies limited to larger cities.

\section{The Human Relations Approach Toward Governing}

With a focus on medium-sized cities in the United States and considering the changing demographics, this article encourages mayors and scholars to think beyond the Black-White, 'us vs. them' dyad. Instead, with examples from two mayors, the hope is to envision the development of policies that can both integrally serve the constituencies with the most need (including, but not limited to Blacks) and everyone simultaneously. Adapting what scholar Cornel West suggests in Race Matters (1993) is a human relations approach to solving the pervasive problems that plague Blacks in many American cities is important in a mayor's effort to actively pursue, and implement policies and programs designed to improve

medium sized cities, the analysis is based on interviews of politicians and civic leaders beyond the mayor's office.

7 United Nations' Department of Economic and Social Affairs

Population Division accessed via http://www.un.org/esa/population/unpop.htm.

Retrieved 2009-06-20 


\section{Ethnic Studies Review Volume 32.1}

the quality of life of Black residents. The human relations approach is best defined as governing directed with an explicit appeal to people's common humanity.

For West, a new framework is needed that views Blacks and their presence in American life as American. Such a framework should "begin with a frank acknowledgment of the basic humanness and Americanness of each of us." ${ }^{8}$ Other scholars have also called for a full integration of Black Americans' social and economic problems into the patchwork of American society (Cunnigen 2006). While West's and Cunnigen's observations, hereby labeled a human relations approach, are conceptual in nature, they can be applied to Black mayoral representation of Black interests in non-majority Black cities. The hypothesis generated is that in their efforts to represent Blacks by universalizing their interests in the non-majority Black context, Black mayors may find success in appealing to the shared and common, human condition of life experience. This approach may allow the mayors to actively pursue Black interests without their majority White constituency feeling threatened that their interests are taking a back seat.

Additionally, this human relations approach, if embraced by mayors, could have a direct racial benefit without the specter of preferential treatment. Notably, this approach contrasts with the 'best way' suggested by some scholars to help the disadvantaged (Wilson 1990). The human relations approach, on the other hand, has the potential to help scholars understand how a Black mayor can actively pursue policies and programs that work to improve the quality of life of Black Americans in the twenty-first century. Elected in cities with comparable demographics to the nation's first Black mayors, many Black mayors in the modern era govern in the non-majority Black context with favorable race relations visà-vis the nation's first Black mayors. With a new century of Black mayors came a change in perspective as to how to garner support for policy and program development in the interests of Blacks.

\section{Black Mayors and the Representation of Black Interests}

There is a large body of scholarship on the governing of Black 8 Ibid, 8. 


\section{Perry-Black Mayors in Non-Majority (Medium-Sized) Cities}

mayors and their Black communities (Nelson 1982; Woody 1982; Piliawsky 1985; Stone 1989; Sonenshein 1993; Orr 1999; Reed 1999; Rich 1999; Moore 2002; Bowers and Baker 2000; Perry 1996; Grenell and Gabris 2000; Thompson 2006). Much of the literature, however, focuses on single-issues, such as education, or housing development, for example.

While scholars recognize the structural limitations Black mayors face (Reed 1999; Keller 1978; Nelson 1992; Nelson and Meranto 1977; Preston 1976; Nelson 2006), they also have found that even given such constraints, they can impact policy. Urban scholars have attempted to ferret out those conditions that are more likely to lead to Black and White mayors having an impact on local policy. Pressman (1972) introduced a model that focused on the financial, political, and personal resources available to a mayor and found, however, that there are significant informal attributes or resources at a mayor's disposal that, when used effectively, can make up for the limited 'formal' authority of some mayors.

On the other hand, several Black mayors have been able to make some substantive changes for African-American residents within the formal constraints of the mayor's office. A number of these mayors did not enjoy many of the preconditions laid out by Pressman (1972). Harold Washington's tenure in Chicago is a vivid example. Washington is generally recognized as having put in place policies that -- had he not faced an untimely death -- could have potentially helped Blacks in Chicago. Though Washington enjoyed Pressman's preconditions such as mayoral jurisdiction to create social welfare programming, and a full time salary as mayor, in many efforts he lacked support from a key governing body, the Chicago city council. Washington also inherited a city without a financial surplus.

Nevertheless, as Judd and Swanstrom $(1994,384)$ note of his first term, Washington was able to "create a more open and participatory atmosphere in city government" by including numerous agencies and community organizations in his office's consultations about social policy, housing and economic development policy. Many of these groups werepredominantly African American in composition. As Mier and Moe $(1991,77)$ found, a critical feature of Washington's 


\section{Ethnic Studies Review Volume 32.1}

plan for economic development involved minority participation. The number of minority firms receiving city contracts increased from nine to sixty, in a three-year period under Washington.

Jones $(1978,116)$ observed a similar network of support for Maynard Jackson in Atlanta after his administration's creation of an office of contract compliance. The result of this policy change was that minority participation in city contract work rose from two percent soon after Jackson took office to thirteen percent near the end of his first term. Noticeably, Jackson faced opposition, especially from Atlanta's White business elite. However, Jones notes that Jackson rebuffed some criticism and attempts at stalling the project, and others like it, in large part because of active groups who assisted his efforts. Jackson's success in reordering some of Atlanta's municipal priorities toward the benefit of the Black community was a large result of ideologically congruent, active group participation. According to Jones, mayoral constraints and limitations make it difficult for Black mayors to reorder "existing priorities." Nevertheless, "a more equitable share for the black community within existing priorities is possible."

Nelson $(1982,191)$ writes about Carl Stokes' ability to garner funds for the construction of 5,496 low to moderate income housing units by the end of his second term, despite the resistance from city council. Even in the face of "threats," Stokes "assisted black businesses by initiating a policy that encouraged competitive bidding by black firms for city contracts." Nelson credits Stokes' "activist-entrepreneur style of leadership." In short, many scholars have concluded that there is room for a Black mayor, even in a non-majority Black city, facing considerable financial and political opposition, to actively pursue policies that are designed to improve the lives of Black residents. In general, the literature speaks to the limitations of Black mayors to affect change in policy, but also to the possibilities, within such constraints, that are available to mayors. Whether they adopt a leadership style of Stokes' "activistentrepreneur" approach or enjoy much of Pressman's preconditions, Black mayors are capable of producing such change for Blacks. As Reed $(1999,98)$ eloquently summarizes, "it is not necessarily the case that those [Black mayoral] regimes are so tightly hemmed 
in by absolute paucity of fiscal resources that they have no span for intervention." To create more favorable conditions to implement such policy, we have seen that Black mayors benefit largely from soliciting the support of active groups who share their administration's goals. These supportive groups may be a key determinant of a Black mayor's success at such efforts.

\section{The Independent Variables}

Based on the literature, I was able to generate the following propositions about conditions under which Black mayors of nonmajority Black cities are more or less likely to actively pursue policies and programs designed to improve the quality of life of Black residents:

\section{More Likely}

Proposition 1: Elected in liberal cities (Browning, Marshall and Tabb, 1984); Proposition 3: Institutional and formal powers of a strong-mayor system (Svara 1994; Pressman 1972); Proposition 4: African-American predecessor(s) (Nelson 2006); Proposition 6: Large White middle class population (Stone 1989); Proposition 7: Active, mobilized and organized Black community (Nelson 2006, Burns 2006); Proposition 8: Black City Council Members (Jones 1976; Karnig and Welch 1980); Proposition 9: Major Newspaper Endorsements (Tate 2004; Burns 2006); Proposition 10: Large proportion of Latinos.

\section{Less Likely}

Proposition 2: Elected in racially divided election campaign (Metz and Tate 1995, Perry 1996); Propositions 5: Large working class White population (Huckfeldt and Kohfeld 1989).

This article details Black mayors' active pursuit of Black interests by universalizing the interests of Blacks. The evidence for the universalizing claim is derived from the application of the propositions and additional factors that may impact Black mayors' efforts to address Black interests to the mayoral administrations of two Black mayors in Ohio. The selected case studies of mediumsized, non-majority Black cities of Dayton and Toledo, Ohio and the focus on the tenure of the Toledo's first Black mayor, Jack Ford (2002-2006) and Dayton's third Black mayor Rhine McLin 


\section{Ethnic Studies Review Volume 32.1}

(2002-present), are tested examples that support the findings of universalizing Black interests within this article.

\section{Dayton and Toledo, Ohio}

The selection of Dayton and Toledo Ohio as case studies was significant. Dayton, in southwest Ohio, has an estimated population of 155,461 (45\% Black), and Toledo, in northwest Ohio, has an estimated population of 316,851 (26\% Black). Hence, the two cities are comparable in population to a number of cities in which many Americans live. Second, the cases of Dayton and Toledo are representative of a wave of Black mayors elected in other cities in Ohio in the twenty-first century. As the following table indicates, most every major city in the state of Ohio elected a Black mayor in the twenty-first century:

\section{$21^{\text {st }}$ Century Black Mayors in Ohio}

Given the noted demographics of the two cities and the regional electoral context in which Ford and McLin governed, their efforts may be representative of options available to other mayors interested in representing Black interests in cities with similar demographics.

\section{Changing Local Demographics and their Implications for Black Mayoral Politics}

Changes in the U.S. population in the last two decades have eroded or are potentially eroding a key variable in the election of Black mayors - a Black population majority. With cities losing Black population while gaining Whites and Latinos, the conditions under which Black candidates run for mayor in many U.S. cities is quite different from the experience of the first elected Black mayors. For example, Washington, D.C. lost sixteen percent of its Black population since 1990. Since 2000, the Black population decreased by six percent. Yet, during the same time period, the District experienced increases in White population, with a fourteen percent increase since 2000. As of 2007, the District had a Black population of fifty-five percent as compared to a Black population over seventy percent in $1980 .^{9}$

9 Washington Post, "D.C. May Be Losing Status As a Majority-Black City" May 
Perry-Black Mayors in Non-Majority (Medium-Sized) Cities

\begin{tabular}{|c|c|c|c|}
\hline Term(s) & Mayor & City & Notes \\
\hline 1999-present & Michael Coleman & Columbus & $\begin{array}{c}\text { City's first Black } \\
\text { mayor. }\end{array}$ \\
\hline 2002-2006 & Jack Ford & Toledo & $\begin{array}{c}\text { City's first Black } \\
\text { mayor }\end{array}$ \\
\hline 2002-present & Rhine McLin & Dayton & $\begin{array}{c}\text { City's first female } \\
\text { mayor }\end{array}$ \\
\hline 2006-present & Mark Mallory & Cincinnati & $\begin{array}{c}\text { City's first popularly } \\
\text { elected Black mayor }\end{array}$ \\
\hline 2006-present & Frank Jackson & Cleveland & $\begin{array}{c}\text { City's third Black } \\
\text { mayor }\end{array}$ \\
\hline 2006-present & Jay Williams & Youngstown & $\begin{array}{c}\text { City's first Black } \\
\text { mayor }\end{array}$ \\
\hline
\end{tabular}

Atlanta, Georgia also experienced a loss of Black population. Since 1990, the White population increased six percent, totaling thirty-seven percent of the population. Black population during the same period decreased nearly twelve percent, to fifty-five percent in 2006. Between 1990 and 2006, the Latino population also increased to 2008 levels approaching six percent. According to Atlanta mayor, Shirley Franklin, the Black population shifted from nearly a two-thirds majority of seventy percent in 1980 to less than sixty percent post $2000 .^{10}$ These data are suggestive of trends where, if they continue, ambitious Black candidates for mayor will find their electoral coalitions comprised of increased numbers of Whites and Latinos in areas where Blacks have dominated for decades.

A decline in Black population across many cities is not the entire story, however. In some cities, the total share of Black population has increased as many Whites moved out, while the White population in other cities declined (Brookings Institution 2001). The White/Black dyad concerning population suggests varying shifts - some cities lose Black population while gaining Whites; others cities lose White and Black population. In either event, the compelling story is the fluctuation of White and Black populations in many U.S. cities, coupled with an increase in Latino population - although only marginal in some cities. One of the

$17,2007$.

10 "Atlanta Mayor: Shrinking Black Population Could Hurt Social Policies," Cox News Service, June 2, 2007 
most important observations, then, is a loss in the share of the percentage of the total population for African Americans for many cities - whether or not Black population declines -- but especially so, when it does.

According to the U.S. Census Bureau and survey reports, Newark, New Jersey had a Black population of nearly sixty percent in 1990, yet by 2008 the Black population declined to fifty-three percent. Rising crime and Black middle class exodus out of the city limits has been cited as a possible reason for the decline. New Orleans, Louisiana is another example, where, in part due to the 2005 Hurricane Katrina, Black population declined. A survey commissioned by several state agencies and reported in the New York Times indicated that the city pre-Katrina had a Black population of sixty-seven percent, and post-Katrina, the population in 2008 was approximately forty-six percent. Some scholars cite Blacks' exit to the suburbs as the reason for numeric decline (Frasure 2007). For example, Blacks in Washington, D.C. are said to be moving into suburbs such as Prince George's County, Maryland, whereas Atlanta, Georgia's Blacks are said to be moving into suburbs such as Stone Mountain and Decatur. Thus, while the reasons for decline in Black populations across many cities vary, the fact of the decline in Blacks' share of the population remains.

As a result, given the changing demographics in many cities, it is expected those Black mayors will soon govern cities with nonmajority Black populations, if they do not already. Thus, one reason why it is important to study two medium-sized non-majority Black cities and their Black mayors' efforts to address Black interests is to contribute to our understanding of the implications of these national trends. Given the entrenched history of Black politics in many cities nationwide, even with the pending shift to non-majority Black status, those mayors will likely be expected to continue to actively pursue Black interests.

At issue, is how, if at all, the representation of Black interests is changing. The demographic trends indicate that researchers may no longer be able to count on descriptive characteristics as a proxy for a Black politician's promotion of Black interests. With many cities changing from Black majority populations to Black minority 


\section{Perry-Black Mayors in Non-Majority (Medium-Sized) Cities}

populations, Black mayors will increasingly find themselves having difficulty justifying promotion of Black interests, at the exclusion of White and Latino interests, for example. Given the increasing diversity of America's population, the skill of advancing one group's interests becomes more complex, especially when it comes to White $v$. Black or Black v. Latino relative to the allocation of resources.

\section{Assessing Black Quality of Life}

In an effort to better code and define particular mayoral efforts as substantively meaningful attempts to improve "Black quality of life," I developed a political typology that can be used to classify a given mayor's activities. The placement of activities within a particular category structures the range of representative efforts from the largely descriptive to the seminally substantive. This range serves as the frame for describing what constitutes quality-of-life improvements. I have conceptualized five essential categories. For any given mayoral effort, a value of one is low, indicating that the mayor made only a relatively symbolic attempt to improve Black quality of life, while a value of five is high, since activities placed in category five are presumably the more difficult to pursue. Each category provides a context describing how a mayor might achieve his or her goals and indicates how he or she has prioritized policy decisions through administrative management.

1. The Politics of Shared Racial Experience. Evidence of mayoral responsiveness and recognition of Black constituent concerns is manifested in symbolic gestures situated within the context of shared racial experience. One example in which a mayor expresses his or her shared racial experience with his or her constituents is Harold Washington's 1983 campaign slogan, "It's our turn" (Kleppner 1985, 155). Another might be the mayor's officiating in the marriage ceremony of his Black constituents (Lane 2001, 61). Noticeably, in these examples, the mayor and his constituents are drawn together by Black Americans' common experience of slavery and institutionalized racism, not by their class or other life attributes. It is difficult to measure how strongly such shared Black experiences are reflected in a mayor's active pursuit of certain policy priorities, however. Within this context, Blacks 
are also diverse, and there are obviously individual differences in how much intensity Black mayors will exercise in addressing Black constituent interests.

2. Access and Opportunity: The Policy Incorporation of Black Interests. Evidence of Black mayors' attempts at incorporating and mobilizing Blacks most notably includes their appointment and hiring of qualified African Americans in visible, significant positions across the spectrum of city government. In the example of hiring practices, the Black mayor is presumably making a political and economic contribution to the lived experiences of qualified African Americans. Establishing employment opportunities for some Blacks is an expression of shared racial experience, particularly when Blacks were not given the same level of access and opportunity in prior or subsequent administrations of White mayors. A mayor's active pursuit of hiring and appointing qualified Black men and women, then, makes a difference for politics and power.

3. The Politics of Constituent Service. In this context, evidence of a Black mayor's active pursuit of policies and programs that are designed to improve the quality of life of Black residents is more concrete. Constituent services include the bulk of municipal service, including but not limited to, neighborhood street-cleaning, paving, and development, trash removal, snow plowing, tree stump removals and improved street lights and signs.

4. Programs for Black Middle-Class and/or Low-Income Residents. Evidence in this policy or programmatic arena is multilayered, as the beneficiaries might extend beyond the Black community. In the allocation of city contracts, for example, are contracts awarded according to the city percentage requirement by the city's good faith goals? Does the mayor monitor the allocation of the contracts in a way that is fair and equitable to ensure minority contractors have access and opportunity to apply? ${ }^{11}$ In a community where African

11 For example, according to Mier and Moe (1991), Harold Washington increased the contracts awarded to minority firms in the city of Chicago from 9 to 60 in a three-year period. However, we have no idea to what extent this meets a city ordinance or good faith goal that requires a certain percentage of minority participation in the contracting process. Without that clear understanding, the stated increase during those three Washington years could be substantively meaningful or simply symbolic. It could be significant, for example, if minority contractors received the average of the total dollar amount relative to their 
Americans are disproportionately poor, moreover, what programs has the mayor introduced that may have broad appeal and at the same time strongly meet the particular interests of Blacks? Policies that are designed to provide neighborhood redevelopment and renovation, for example, such as HUD's HOPE VI programs, may have broad appeal to low-income residents and at same time significantly meet the interests of Blacks. This area of policy concern might largely be considered community development. Brown $(2007,26)$ is an example of scholarship that focuses on such social welfare-defined policies and programs.

5. Substantive Management Priorities. Finally, mayors may actively pursue expensive social welfare policies and programs that work to improve the quality of life of African Americans. These policies and programs may improve access to health care, (such as the introduction of a health care network for the uninsured or a citywide smoking ban), or they may include increased employment opportunities for minority youth, or the substantive support of the financial and academic status of the city's public school system.

Each category in the typology reflects a different level of responsiveness to Black citizens' interests. The typology provides a structured mechanism from which to evaluate the extent and breadth of mayors such as Ford and McLin and their active pursuit of policies and programs that work to improve the quality of life of Black residents.

\section{Evaluating the Propositions}

Earlier, I generated ten propositions derived from the literature review that are designed to gage the conditions under which Black mayors would actively pursue the interests of Blacks in non-majority Black cities. My analysis of the mayoral efforts of Ford and McLin identified that some of these propositions were confirmed, while others remained unconfirmed. Moreover, findings were unearthed that were not originally expected.

\section{Confirmed Propositions}

The evidence from the case studies of Dayton and Toledo supports three propositions. Proposition three, that Black mayors 


\section{Ethnic Studies Review Volume 32.1}

who have the institutional and formal powers of a strong-mayor system are more likely to actively pursue policies designed to improve the quality of life of Black residents, was demonstrated. While both Ford and McLin pursued Black interests, Ford did so more substantively, and it seems this difference was due to the presence of the institutional and formal powers of a strong-mayor system in Toledo but not in Dayton.

Proposition six, that Black mayors who govern in cities with a large White middle-class population are more likely to actively pursue policies designed to improve the quality of life of Black residents, was also confirmed. Toledo had a higher household median income and higher White median family income (in 1999 dollars) than Dayton, Ohio. While the findings do not tell us whether it was this variable that determined Ford's greater pursuit of Black interests, the fact of the larger White middle-class population in the city where the mayor was found to have more actively pursued Black interests is notable.

Finally, proposition eight, that Black mayors who serve on city councils in which African-Americans are a majority or a substantial minority are more likely to actively pursue policies designed to improve the quality of life of Black residents, was confirmed. When Ford was mayor of Toledo, the city council had three Black members, two elected from districts and one elected at-large. The presence of Black members of council had a significant impact on the passage of the few mayoral agenda items that needed council approval, though Ford tid also needed the support of White liberal members of council. For McLin, the city commission had two additional Black council members, though one was not an avid supporter of her 2001 election. Additionally, on some issues, the Black commission members did not support McLin's agenda, whereas two libera! White members did. Hence, the presence of Black council members is a necessary but not a sufficient condition for mayors of non-majority Black cities to actively pursue Black interests.

\section{Four Additional Findings}

In addition to the confirmation of three propositions, four 
additional findings were determined to be significant. The four major conditions under which a Black mayor of a non-majority Black city actively pursues policies and programs that work to improve the quality of life of African Americans are: the presence of a strong mayor form of government, the presence of ideologically congruent council members, the existence of effective business relationships, and a mayoral personality and style that is beneficial to community members' perception of the mayor.

The finding of the importance of a strong-mayor form of government confirms much previous research. The finding is significant in the case studies; it confirms the importance of mayoral structure in medium-sized cities, as well as the limitations of a weakmayor system, the system of government under which most Black mayors govern. ${ }^{12}$ The finding also helps to explain the consequences of high expectations. If a majority of Black mayors govern within a system where the mayor is structurally unable to make significant strides to meet Black expectations, Blacks may continue to grade Black mayors less favorably than their White predecessors.

The finding that ideology trumps race to some extent in respect to council members' support of mayoral agenda items is significant because it demonstrates the usefulness of the political representation debate in political science literature. One school argues that race trumps party (Tate 2004), while the other argues that party trumps race (Swain 1996). The finding in Toledo and Dayton, however, was that the presence of minority councilors mattered, but not as an end of itself. Rather, mayors needed the support of ideologically congruent councilors of other racial groups to ensure enough votes to pass agenda items. Thereby, the finding, in part, confirms both of the opposing arguments within the political representation debate.

The finding that the presence of effective business relationships

12 For more information, see "The Future of Local Government Administration: The Hansell Symposium," Washington, D.C.: International City and County Management Association, 2002; and Svara, J. "Effective mayoral leadership in council-manager cities: Reassessing the facilitative model," National Civic Review, July 2003 Volume 92 Issue 2, Pages 157 - 172; Statement regarding the number of Black mayors in weak mayor systems is based on November 2008 data from the National Conference of Black Mayors website indicating the number of Black mayors of cities with population over 50,000. 
plays a significant role in whether or not a Black mayor advocates for Black interests in non-majority Black cities confirms earlier scholarship which found that the business community was integral to a Black mayor's success (Stone 1989). Additionally significant is the finding that Black mayors who are not perceived to have an understanding of business will be limited in their ability to finance desired city programs or a re-election campaign. The fact that the business community, including union leadership, can be a large contributor to mayoral campaigns in medium-sized cities with union cultures like Toledo and Dayton is important, as it pinpoints the electoral and governing coalitions necessary for substantive change: both coalitions benefit from having business members playing active, supportive roles.

Finally, the finding that the mayor's personality style and approach toward governing plays a significant role in efforts to impact Black quality of life is significant because it confirms previous scholarship on the roles and different types of mayors, given varying governmental power structures (Kotter and Lawrence 1974; Svara 1994). Additionally, the finding suggests that the extent to which a Black mayor is able to advocate for Black interests is largely within the mayor's own control. While structural impediments are often insurmountable within a term or two, a mayor does have the ability to affect the way he or she is perceived by others.

\section{The Focus on Common Humanity: Universalizing the Interests of Blacks}

Jack Ford and Rhine McLin are found to be examples of mayors who did not explicitly advocate for race policies. However, neither did they seek the fulfillment of race-specific policies by deemphasizing race (or replacing a racial label with the 'urban' label) — through deracialization. ${ }^{13}$ Rather, Ford and McLin are examples of twenty-firstcentury Black mayors of non-majority Black cities who were successful in their active pursuit of policies and programs designed to improve the quality of life of Blacks because they noted the racial significance

13 For an example of how the Deracialization approach was and is used by scholars to explain the political behavior of Black elected officials see McCormick II and Jones (1993: 66-84) and for a more recent examination see Persons (2007, 92-94). 
of supported policies and programs where appropriate. ${ }^{14}$

\section{The Universalism and Targeted Policy Debate}

The question of how best to implement social welfare and urban public policy initiatives has most recently been debated in terms of initiatives' universal or targeted impact and has received much scholarly attention. ${ }^{15}$ Sociologist William Julius Wilson and political scientist/sociologist Theda Skocpol are often cited as supporting a universalistic approach to public policy implementation (Midgley, et al 2000; Greenstein 1991). Economically based, universally applied social programs, Wilson argues, will address racially disparate problems in inner-city communities and the "substantive inequality" that would remain if the policy focus was limited to race-specific policies and means-tested goals and objectives. ${ }^{16}$ Consequently, universalistic policies and programs can have targeted benefits for African Americans in the urban context. ${ }^{17}$

Focusing largely on Social Security and Medicare, Skocpol (1991, 1995) has agreed with Wilson that social welfare and urban public policy programs require universalistic benefits. Hence, scholars who champion the universalism approach toward social welfare and urban public policy programs that may benefit particular constituencies like Blacks allege that policymakers' efforts should

14 A thorough analysis of Ford and McLin's policy actions and program developments on behalf of Black interests is detailed in my dissertation.

15 See, for example, Grogan and Patashnik 2003; Anttonen 2002; Manza 2000; Mkandawire 2005; Barnett, et al 2004; Baker and Feldman 2004; Dynarski 2002; Roberts 1996; Skocpol 1990, 1991, 1995; Wilson 1987, 1991, 1996; Greenstein 1991; Wilkins 1989; Massey and Denton 1988, 1989, 1994; Massey and Eggers 1990; Boger 2000; Hasenfeld 1997; Midgley, et al 2000; Rosanvallon and Harshav 2000.

16 Ibid, 146.

17 In the urban context, Stone's (1989) regime theory perhaps is comparable. Regime theory assumes a political economy perspective and maintains that class is the leading variable to consider in urban politics. It follows, then, that proponents of regime theory may favor a class-based approach to solve urban social problems, including those which disproportionately plague Black urban constituencies. However, Stone's view is not uniformly followed. For example, the views of scholars such as Nelson (2000) and Kraus (2004), who find that the approach does not adequately address the racial variable prevalent in the urban context, are perhaps most comparable with scholars like Greenstein (1991) who finds universal policies to address national social problems through public policy are limited. 
be guided by fundamental values and moral obligations that are alleged to be monolithically understood or accepted.

Not all scholars agree with Skocpol and Wilson. ${ }^{18}$ For example, Greenstein (1991) argues that Skocpol makes incongruent comparisons between universal programs that provide entitlements to targeted programs that do not. Greenstein finds that Skocpol overstates the success of universal programs by "using programs for the elderly as her primary example and describes how Skocpol compares programs that provide entitlements for the elderly with programs that are not focused on the elderly and "are not considered earned benefits. ${ }^{\prime 19}$

Opponents of Universalism: Universalism within Targeting or Targeted Universalism

Similar to Greenstein's proposal to combine the targeted and universal approaches in an effort to substantively address social welfare policies, powell (2008) has argued that universal laws and policies do not effectively address the needs of Black and urban communities. powell argues for targeted universalism in race politics, in which arguments are made in way that is racially inclusive rather than polarizing. powell's reference to "targeted universalism" is similar to Skocpol's notion of "targeting within universalism," wherein extra benefits are directed to low-income groups within the context of a universal policy design (Skocpol 1991: 414; Midgley et al. 2000; Grogan and Patashnik 2003). ${ }^{20}$ As an example of targeting within universalism, Skocpol cites the hypothetical development of a family security program as an extension of pre-existing social security programs for the elderly (429).

powell's (sic) targeted universalism has a different focus. He describes why universal, race-neutral policies are ineffective in race politics:

18 For example, see Wilkins (1989), Massey and Denton (1988, 1989, 1994), and Massey and Eggers (1990).

19 Greenstein, 444.

20 The inverse of 'targeting within universalism' is 'universalism within targeting,' "a pattern that can arise whenever a targeted program's threshold of means-tested income is set high enough that a significant number of people from mainstream backgrounds qualify" (Grogan and Patashnik 2003; Gilbert 2001). An example of such a program, cited by Grogan and Patashnik, is the reliance of senior citizens in nursing homes on Medicaid. 


\section{Perry-Black Mayors in Non-Majority (Medium-Sized) Cities}

Policies that are designed to be universal too often fail to acknowledge that different people are situated differently. For racially marginalized populations, particularly those who live in concentrated-poverty neighborhoods, there are multiple reinforcing constraints. For any given issue whether it is employment rates, housing, incarceration, or health care - the challenge is to appreciate how these issues interact and accumulate over time, with place as the linchpin holding these arrangements together. Universal policies that are nominally race-neutral and that focus on specific issues such as school reform will rarely be effective because of the cumulative cascade of issues that encompass these neighborhoods. ${ }^{21}$

Thus, powell argues for the necessity of a policy and programmatic approach that acknowledges that any social problems affect more than just Blacks, yet still require targeted implementation.

In addition, proposed remedies, such as affirmative action, should examine a broader array of factors than race alone. ${ }^{22}$ powell's "targeted universalism" is a strategy that achieves what racialized politics attempted in the 1960s and 1970s with, for example, programs focused on urban renewal. In a new era in which scholars at least question how a preference for diversity in the job sector may negatively impact Blacks (Jaynes and McKinney 2003), powell (2008) recognizes that racialized efforts are ineffective and that universal interests deny the specter of race.

powell's concept of targeted universalism is a political strategy and governing approach that recognizes the need for a universal platform that is simultaneously responsive to the needs of the particular. By extension, then, targeted universalism is a rhetorical strategy and also potentially a public policy program development strategy wherein policy output is determined in part by how a program effectively can be described as benefiting all citizens, yet

21 john a. powell, "Race, Place and Opportunity" The American Prospect, September 22, 2008

22 "Revisiting 'The Rage of a Privileged Class," Ellis Cose, Newsweek, February 2, 2009 
with a targeted focus toward the problems of specific groups.

powell cites Los Angeles mayor Antonio Villaraigosa and Chicago mayor Harold Washington as examples of public officials who actively utilized the approach successfully: both of these men "built broad-based multi-racial, multi-class coalitions and succeeded by keeping both race and class issues in focus ... There has never been-at least in 20th Century America-a progressive political movement built solely on class. To inoculate such efforts from divisive race-baiting, there must be discourse to inspire whites to link their fates to nonwhites" (powell and Menendian 2006). ${ }^{23}$ What powell considers targeted universalism I characterize as Toledo Mayor Jack Ford's and Dayton Mayor Rhine McLin's efforts to universalize the interests of Blacks. In these attempts, the mayors garnered White support for seemingly racialized initiatives. In the context of cities with similar demographics, similar evidences of these mayors' efforts may be found in other cities. If followed, the Black mayors' reelection may be threatened, as McCormick and Jones $(1993,78)$ note, however, at the very least they have initiated a discourse on racial equal opportunity that potentially can affect the city culture for years to come.

As proponents of targeted universalism have argued, though, while an opportunity for positive discourse may develop out of a targeted universalistic approach, the approach has significant problems. As Young (1990) has indicated, notions of what is universal are understood insofar as they stand in contrast to background assumptions that are particular, or non-universal. When it comes to universal public policies and how best to implement them, however, often such policies, even if targeted under the framework of universalism, tend to be perceived as racially polarizing.

23 I cannot definitely describe the examples of the mayors' efforts powell lists. However, Washington's neighborhood improvement program in Chicago and William A. Johnson, Jr.'s similar program in Rochester appears to be examples of universal programs that benefited all city neighborhoods, but also provided resources to Black neighborhoods as well. For more information of Washington's neighborhood efforts, see Clavel and Wiewel (1991). For more information on Johnson's neighborhood efforts, see Clavel (2007). In both texts, the authors cite how the universal neighborhood programming, like Johnson's creation of Neighbors Building Neighborhoods, improved the quality of life in the city's minority neighborhoods. 
President Johnson's aforementioned War on Poverty programs are one example: though these programs were promoted in universal language, many White citizens felt their tax dollars were being spent to benefit Black people. Some scholars have noted, moreover, that Aid to Families with Dependent Children, a universal program, came to be perceived as predominantly for the Black urban poor (Gilen 1999). Even though Blacks were disproportionately excluded from the program when it was first established, demographic changes and changes in the development of media led many Americans to believe poor Blacks were the dominant group affected by poverty. Thus, according to some scholars, most universal programs are de facto targeted or particular, either because of how they are perceived or in terms of how their benefits are implemented (see Lieberman 2001, 227-28). In the final analysis, then, it appears that particularly at the implementation stage, targeted universalism can become racialized.

What remains is that the practice of universalizing the interests of Blacks is not the same thing as deracialization, and as a result, is conceivably a better option for mayors, even if its targeted focus is not perfect. The universalizing approach is different, as the process includes Black elected officials that take the interests of Black constituents, develop particularized policy actions and program developments, and popularize them by rhetorically advocating for these interests in a way that does not deemphasize race or alienate all Whites. The context in which this process functioned in the case studies was one in which the mayors emphasized citizens' common humanity. Hence, in addition to noting the significance of race while supporting certain policies and programs, the mayors carefully tapped into the common humanity of city residents through strategic rhetorical framing, mainly in State of the City addresses and related speeches. As a result, the mayors received support for their causes in neighborhoods and groups not their own. Their approach is a good example of how to maintain some White electoral and governing support in a non-majority Black city while at the same time, advocating for Black interests. ${ }^{24}$

24 The alternative approaches to universalizing the interests of Blacks are racialization and deracialization. However, the universalizing approach is likely the most effective of these three options. The racialization approach is largely ineffective not because it fails to produce substantive results but rather, due 
While McCormick and Jones (1993) note that White support is necessary to implement a Black elected official's race-specific policies, the variable of political ideology is omitted in their analysis. As the case studies within this article showed when Black elected officials defuse race in their pursuit of public office, yet not in their policy implementation after they win, White liberals may support a Black mayor's Black interest agenda items. In the modern era, shared ideology between a Black politician and a White politician may trump Whites' supposed race-based opposition to Blackfriendly policies. Ford and McLin's ability to court White support for their efforts on minority contracting and housing, respectively, stand out as examples of White support for programs and policies that had the effect of improving Black quality of life.

Though the racialization approach may be more effective at substantively addressing Black interests (Cruse 1990), the social and political climate of the twenty-first century largely makes the effective utilization of that approach impossible. Moreover, while the deracialization approach is likely the most popular among Black elected officials, it has been shown, at least in the case of Atlanta, to have limited effects on disadvantaged Blacks (Sjoquist 1988; Stone 1989; Jones 1990). Additionally, the approach inherently assumes that Whites in general are against race-specific policies, which ignores the ideological congruence of some Whites and Blacks. In other words, liberal White policy makers and voters have supported the implementation of Black programs directly through public policy or indirectly by supporting a Black candidate whom they perceived might implement such policies (Browning,

to a cultural and demographic shift that has occurred since the 1970s. The deracialization, or race-neutral, universal perspective, suggests that race-specific issues are polarizing in campaign rhetoric and governance and that race-specific rhetoric must be defused and avoided by political actors. I argue that this approach is increasingly exhausted as well. The fact that this approach attempts to transcend race-specific policy in favor of mobilizing a diverse coalition of electoral and governing support suggests that it places any direct attention to racial disparities and municipal problems that may disproportionately affect one race more than another out of bounds. Yet deracialized policies often manage to help the Black community only to a limited extent. For example, the approach, to which is famously attributed the rise of the Black middle class and Black political governance in Atlanta, has noticeably had little effect on the city's poorer Black community (Sjoquist 1988; Stone 1989; Jones 1990). 


\section{Perry-Black Mayors in Non-Majority (Medium-Sized) Cities}

Marshall, and Tabb 1984, 220). Hence, while Kinder and Sanders (1996), Feldman and Huddy (2005), and others have noted Whites' "racial resentment" of race-specific policies, some Whites who can be defined as ideologically liberal have in fact supported racespecific policies and programming. ${ }^{25}$

The Genesis of the Humanity-Based Approach

Cornel West arguably began the common-humanity, humanrelations theoretical reasoning for public policy in Race Matters (1993). West argued that a new framework was needed in order to effectively engage in a serious discussion of race in America. He noted that, "we must begin not with the problems of black people, but with the flaws of American society" (6). To that end, West suggested that the new framework must include reference to our common humanity and he commented that any serious discussion of race in America should not be limited to the Black experience.

West suggested that to ignore race would be perilous, but he also understood that explicit racial appeals had exhausted themselves in favor of a process that invokes the shared human experience. Thus, he argued that a new framework must recognize the role of race while not exploiting it. In his estimation, what is to be done is to

admit that the most valuable sources for help, hope, and power consist of ourselves, and our common history . . .

25 Other scholars have noted how Whites may find themselves supporting Black programs. Steele (1990) and Harvey and Oswald (2000), for example, found that Whites' guilt can lead to their support of programs, policies, and laws that support Blacks. Feldman and Huddy (2005), though, have more recently noted the connection between racial resentment and ideology, finding that "conservatives are more likely than liberals to hold highly individualistic beliefs" and that "there are fundamental differences in the character of racial resentment for liberals and conservatives" (178). In the final analysis, however, they maintain that "it is difficult to conclude that resentment constitutes a clear measure of ideology among conservatives." That finding is based on the fact that the authors found no evidence that "resentment was more closely tied to values like individualism and limited government for conservatives than for liberals." Yet the authors did find that conservative ideology "apparently [had] ideological effects on opposition [to a college scholarship program that is targeted at specific racial groups]." Consequently, while the correlation between racial resentment and prejudice remains undetermined, it remains the case that conservatives oppose race-specific policies and programs more than do liberals. 


\section{Ethnic Studies Review Volume 32.1}

We must focus our attention on the public square - the common good that undergirds our national and global identities. The vitality of any public square ultimately depends on how much we care about the quality of our lives together. The neglect of our public infrastructure, for example ... reflects not only our myopic economic policies, which impede productivity, but also the low priority we place on our common life." ${ }^{\prime 26}$

Perhaps without knowing it, West wrote the handbook for twenty-first-century Black mayors in non-majority Black cities in respect to how they might use the power of their positions to impact the substantive quality of life of Blacks.

\section{References}

Aizenman, N.C. (2007). "D.C. May Be Losing Status As a MajorityBlack City; Washington Post, May 17.

Anttonen, Anneli. (2002). "Universalism and social policy: a Nordic-feminist revaluation." Nordic Journal of Feminist and Gender Research. Vol 10: October pp. 71-80.

Baker, Samuel A. and David H. Feldman. (2004). "Revealed Preferences for Car Tax Cuts: an Empirical Study of Perceived Fiscal Incidence." College of William and Mary Department of Economics Working Paper \#8: November, 1-15.

Barnett, W. Steven, Kirsty Brown and Rima Shore. (2004). "The Universal vs. Targeted Debate: Should the United States Have Preschool for All?" Preschool Policy Matters 6: April, 1-15.

Bayor, Ronald H. (2001). "African-American Mayors and Governance in Atlanta." In African American Mayors, eds. David R. Colburn and Jeffrey S. Adler. Urbana: University of Illinois Press, 178-199.

Biles, Roger. (2001). "Mayor David Dinkins and the Politics of Race 26 Ibid, 11-12. 


\section{Perry-Black Mayors in Non-Majority (Medium-Sized) Cities}

in New York City." In African American Mayors, eds. David R. Colburn and Jeffrey S. Adler. Urbana: University of Illinois Press, 130-152.

Boger, John Charles. (2000). "The Eclipse of Anti-Racist Public Policy." In Race and Ethnicity in the United States, ed. Stephen Steinberg. New York: Wiley-Blackwell.

Bowers, James R. and Paul C. Baker. (2000). "William A. Johnson Jr. and Education Politics in Rochester, New York" In Governing Middle Sized Cities, eds. Bowers, James R. and Wilber Rich. Boulder, CO: Lynne Rienner Publishers, pp 81-102.

Bowers, James R. and Wilbur C. Rich, Eds. (2000). Governing Middle Sized Cities Boulder, CO: Lynne Rienner Publishers.

Brookings Institution. (2001). Census 2000 Matters: Racial Changes in the Nation's Largest Cities: Evidence from the 2000 Census. (April). Washington, D.C.: Brookings Institution Center on Urban and Metropolitan Policy.

Brown, Robert A. (2007). "Race and Politics Matter: Black Urban Representation and Social Spending during the Urban Crisis," The National Political Science Review, Vol.11: 17-41.

Browning, R.P., Marshall, D.R., \& Tabb, D.H. (1984). Protest is not Enough: The struggle of blacks and Hispanics for equality in urban politics. Berkeley: University of California Press.

Burns, Peter F. (2006). Electoral Politics Is Not Enough: Racial And Ethnic Minorities And Urban Politics. New York: State University of New York Press.

Button, James W. (1989). Blacks and Social Change. Princeton, NJ: Princeton University Press.

Clavel, Pierre and Wim Wiewel, Eds. (1991). Harold Washington and 
Ethnic Studies Review Volume 32.1

the Neighborhoods: Progressive City Government in Chicago 1983-1987. New Brunswick: Rutgers University Press.

Clavel, Pierre. (2007). "Rochester: Two Faces on Regionalism." In Economic

Development in American Cities: The Pursuit of an Equity Agenda, eds., Bennett, M. I. J., \& Giloth, R. P. Albany: State University of New York Press.

Clay, William L. (1992). Just Permanent Interests: Black Americans in Congress, 1870-

1991. New York: Amistad.

Cose, Ellis. (2009). "Revisiting 'The Rage of a Privileged Class," Newsweek, February 2.

Cruse, Harold. (1990). "New Black Leadership Required." New Politics 2 (4): 43-47.

Cunnigen, Donald. (2006). "Black leadership in the twenty-first century." Society 43:5 (July): 25-29.

Curvin, Robert. (1972). "Black Power in City Hall," Society 9 (September/October): 56-57.

Dawson, Michael C. (1994). Behind the Mule: Race and Class in African American Politics. Princeton: Princeton University Press.

Dewan, Shaila. (2006). "Gentrification Changing Face of New Atlanta," New York Times, March 11.

Dynarski, Susan. (2002). "The Consequences of Merit Aid." John F. Kennedy School of Government Harvard University Faculty Research Working Paper Series: November, 1-53.

Feldman, Stanley and Leonie Huddy. (2005). "Racial Resentment 
Perry-Black Mayors in Non-Majority (Medium-Sized) Cities

and White Opposition to Race-Conscious Programs: Principles or Prejudice?" American Journal of Political Science. Vol 49: January, 168-183.

Fenno, Richard F., Jr. (2003). Going Home: Black Representatives and Their

Constituents. Chicago: University of Chicago Press.

Firestone, David. (2001). "The Census Shows Growth in Atlanta's Population," New York Times, March 23.

Ford, Jack. (2008). Interview. June 24.

Ford, Jack. (2009). Telephone Conversation. January.

Frasure, Lorrie A. (2007). "Beyond the Myth of the White Middle Class: Immigrant and Ethnic Minority Settlement in Suburban America." The National Political Science Review. 11: 65-86.

Frederickson, H. George and John Nalbandian, Eds. (2002). "The Future of Local Government Administration: The Hansell Symposium," Washington, D.C.: International City and County Management Association.

Frey, William. (2006). Diversity Spreads Out: Metropolitan Shifts in Hispanic, Asian, and Black Populations Since 2000. (March). Washington, D.C.: Brookings Institution Report.

Gamble, Katrina L. (2007). "Black Political Representation: An Examination of Legislative Activity Within US House Committees." Legislative Studies Quarterly XXXII: 421.

Gilbert, Neil, ed. (2001). Targeting Social Benefits. New Brunswick, NJ: Transaction Publishers.

Gilen, Martin. (1999). Why Americans Hate Welfare: Race, Media, and the Politics of Antipoverty Policy. Chicago, IL: University 


\section{Ethnic Studies Review Volume 32.1}

of Chicago Press.

Greenstein, Robert. (1991). "Universal and Targeted Approaches to Relieving Poverty: An Alternative View." In The Urban Underclass, eds. Christopher Jencks and Paul E. Peterson. Washington D.C.: The Brookings Institution.

Grenell, Keenan D. and Gerald T. Gabris. (2000). "Charles Box and Regime Politics." In Governing Middle Sized Cities, eds. Bowers, James R. and Wilber Rich. Boulder, CO: Lynne Rienner Publishers, 181-196.

Grogan, Colleen M. and Eric M. Patashnik. (2003). "Universalism within Targeting: Nursing Home Care, the Middle Class, and the Politics of the Medicaid Program." Social Service Review. (March): 51-71.

Guinier, Lani. (1994). Tyranny of the Majority: Fundamental Fairness in Direct

Democracy. New York: Free Press.

Hajnal, Zoltan. (2007). Changing White Attitudes Toward Black Political Leadership. New York: Cambridge University Press.

Hall, Richard L. (1996). Participation in Congress. New Haven: Yale University

Press.

Harvey, Richard D. and Debra L. Oswald. (2000). "Collective Guilt and Shame as Motivation for White Support of Black Programs." Journal of Applied Social Psychology. Vol. 30: 1790-1811.

Hasenfeld, Yeheskel. (1997). We the poor people: work, poverty, and welfare. New Haven, CT: Yale University Press.

Huckfeldt, Robert and Carol Weitzel Kohfeld. (1989). Race and the Decline of Class in American Politics. Urbana: University 


\section{Perry-Black Mayors in Non-Majority (Medium-Sized) Cities}

of Illinois Press.

Jaynes, Gerald and Frederick McKinney. (2003). "Do blacks lose when diversity replaces affirmative action?" The Review of Black Political Economy Volume 31 (September): Pages 111124.

Jones, Clinton B. (1976). "The Impact of Local Election Systems on Black Political Representation," Urban Affairs Quarterly 11 (March) 345-56.

Jones, Mack H. (1978). "Black Political Empowerment in Atlanta: Myth and Reality." Annals of the American Academy of Political and Social Science (Sept). 439: 90-117.

Jones, Mack H. (1990). "Black Mayoral Leadership in Atlanta: A Comment," in Black Electoral Politics, Lucius Jefferson Barker, (Ed.), National Political Science Review. Transaction Publishers.

Judd, Dennis R. and Todd Swanstrom. (1994). City Politics: Private Power and Public Policy. New York: Harper Collins.

Karnig, Albert K. and Susan Welch. (1980). Black Representation and Urban Policy. Chicago: University of Chicago Press.

Keller, Edmond J. (1978). "The Impact of Black Mayors on Urban Policy." The Annals of the American Academy of Political and Social Science 439: 40-52.

Kinder, Donald R. and Lynn M. Sanders. (1996). Divided by Color. Chicago: University of Chicago Press.

Kleppner, Paul. (1985). Chicago Divided: The Mayor of a Black Mayor. DeKalb: Northern Illinois University Press.

Kotter, John P. and Paul R. Lawrence. (1974). Mayors in Action. 
Ethnic Studies Review Volume 32.1

New York: John Wiley and Sons.

Kraus, Neil. (2004). "The Significance of Race in Urban Politics: The Limitations of Regime Theory." Race and Society 7: 95111.

Lane, James B. (2001). "Black Political Power and Its Limits: Gary Mayor Richard G. Hatcher's Administration, 1968-87." In African American Mayors, eds. David R. Colburn and Jeffrey S. Adler. Urbana: University of Illinois Press.

Large, Jerry. (2002). "Central District: Change Is Inevitable, But Forsaking Past is Regrettable," Seattle Times, November 6.

Lieberman, Robert C. (2001). Shifting the Color Line. Cambridge: Harvard University Press.

Manza, Jeffrey. (2000). "Race and the underdevelopment of the American welfare state." Theory and Society. 29:December, 819-832.

Massey, Douglas S. and Nancy A. Denton. (1988). "The Dimensions of Residential Segregation." Social Forces. 67: 281-315.

Massey, DouglasS. and NancyA. Denton. (1989). "Hypersegregation in U.S. Metropolitan Areas: Black and Hispanic Segregation along Five Dimensions." Demography. 26: 373-393.

Massey, Douglas S. and Mitchell L. Eggers. (1990). "The Ecology of Inequality: Minorities and the Concentration of Poverty, 19701980." American Journal of Sociology 95.

Massey, Douglas S. and Nancy A. Denton. (1994). American Apartheid. Cambridge, MA: Harvard University Press.

McCormick II, Joseph P. and Charles E. Jones. (1993). "The Conceptualization of Deracialization," in Georgia Persons, ed., 


\section{Perry-Black Mayors in Non-Majority (Medium-Sized) Cities}

Dilemmas of Black Politics, Harper Collins: New York, pp. 6684.

McLin, Rhine. (2008). Interview. June 26.

Metz, David Haywood and Katherine Tate. (1995). "The Color of Urban Campaigns." In Classifying by Race, ed. Paul E. Peterson. Princeton: Princeton University Press.

Midgley, James, Martin Tracy, Michelle Livermore. (2000). The Handbook of Social Policy. New York: Sage.

Mier, Robert and Kari J. Moe. (1991). "Decentralized Development: From Theory to Practice." In Harold Washington and the Neighborhoods: Progressive City Government in Chicago 1983-1987, eds. Pierre Clavel and Wim Wiewel. New Brunswick: Rutgers University Press.

Mkandawire, Thandika. (2005). "Targeting and Universalism in Poverty Reduction." Social Policy and Development Program Paper Number 23: December, United Nations Research Institute for Social Development, pp. 1-20.

Moore, Leonard N. (2002). Carl B. Stokes and the Rise of Black Political Power. Urbana: University of Illinois Press.

Nelson, William E. Jr. and Meranto, Philip. (1977). Electing Black Mayors: Political Action in the Black Community. Columbus: Ohio State University Press.

Nelson, William E. Jr. (1982). "Cleveland: The Rise and Fall of The New Black Politics." In The New Black Politics, eds. Michael B. Preston, Lenneal J. Henderson, Jr. and Paul Puryear. New York: Longman Press.

Nelson, William E. Jr. (1992). "Black Mayoral Leadership: A Twenty Year Perspective." In Enduring Tensions in Urban Politics, eds. 


\section{Ethnic Studies Review Volume 32.1}

Dennis Judd and Paul Kantor. New York: Macmillan.

Nelson, William E. Jr. (2000). Black Atlantic Politics: Dilemmas of Political Empowerment in Boston and Liverpool. Albany: State University of New York Press.

Nelson, William E. Jr. (2006). "Black Mayoral Leadership in the Twenty-First Century: Challenges and Opportunities." In Black and Latino/Latina Politics: Issues in Political Development in the United States, eds. William E. Nelson, Jr. and Jessica PerezMonforti. Miami: Barnhard and Ashe Publishers.

No Author. (2007). "Atlanta Mayor: Shrinking Black Population Court Hurt Social Policies," Cox News Service, June 2.

No Author. (2007). "Major Cities Rapidly Losing Black Population: Could Have Major Negative Impact on Black Political Power," Taylor Media Services, September 25.

No Author. "Black or African American Population: 1990-2000 New Jersey Municipalities" Accessed via

http://www.wnjpin.state.nj.us/OneStopCareerCenter/ LaborMarketInformation/Imi25/pl94/cnty/black.PDF. Retrieved 2009-06-20

No Author. United Nations' Department of Economic and Social Affairs Population Division accessed via http://www.un.org/ esa/population/unpop.htm. Retrieved 2009-06-20

Noble, Kenneth B. (1995). "Blacks Say Life in Los Angeles Is Losing Allure," New York Times, January 8.

Orr, Marion. (1999). Black Social Capital. Lawrence: University Press of Kansas.

Perry, Huey L., ed. (1996). Race, Politics and Governance in the United States. Gainesville: University Press of Florida. 
Persons, Georgia. (2007). "From Insurgency to Deracialization: The Evolution of Black Mayoralties" in John Davis, ed., Perspectives in Black Politics and Black Leadership. Lanham, MD: University Press of America.

Phillips, Anne. (1995). The Politics of Presence. Oxford, U.K.: Clarendon Press.

Piliawsky, Monte. (1985). "The Impact of Black Mayors on the Black Community: The Case of New Orleans' Ernest Morial," The Review of Black Political Economy. Volume 13 (March): 5-23.

powell, john a. and Stephen Menendian. (2006). "Race vis-a-vis Class in the U.S.?" Poverty \& Race. November/December.

powell, john a. (2008). "Race, Place and Opportunity" The American Prospect, September 22.

Pressman, Jeffrey L. (1972). "Preconditions of Mayoral Leadership." The American Political Science Review 66: 511-524.

Preston, Michael B. (1976). "Limitations on Black Urban Power: The Case of Black Mayors." In The New Urban Politics, eds. Robert Lineberry and Louis Masotti. Boston: Ballinger.

Preston, Michael B. (1990). "Big City Black Mayors: An Overview." National Political Science Review. 2: 131-95.

Reed, Adolph. (1999). "The Black Urban Regime: Structural Origins and Constraints." In Stirrings in the Jug, ed. Adolph Reed. Minneapolis: University of Minnesota Press, 79-115.

Rich, Wilbur. (1999). Coleman Young and Detroit Politics: From Social Activist to Power Broker. Detroit: Wayne State University Press. 
Ritter, John. (2007). "San Francisco Hopes to Reverse Black Flight," USA Today, August 26.

Roberts, Dorothy E. (1996). "Welfare and the Problem of Black Citizenship." The Yale Law Journal. April: 105, 1563-1602.

Roberts, Sam. (2006). “New York City Losing Blacks, Census Shows," New York Times, April 3.

Rosanvallon, Pierre and Barbara Harshav. (2000). The new social question: rethinking the welfare state. Princeton, NJ: Princeton University Press.

Sjoquist, David. (1988). The Economic Status of Black Atlantans Atlanta: Atlanta Urban League

Skocpol, Theda. (1990). "Sustainable Social Policy: Fighting Poverty Without Poverty Programs." The American Prospect. June 23.

Skocpol, Theda. (1991). "Targeting within Universalism: Politically Viable Policies to Combat Poverty in the United States." In The Urban Underclass, eds. Christopher Jencks and Paul E. Peterson. Washington D.C.: The Brookings Institution.

Skocpol, Theda. (1995). Social Policy in the United States. Princeton, NJ: Princeton University Press.

Smith, Michelle R. (2006). "Study: New Orleans Could Lose 80 Percent of Black Population," Associated Press, January 26.

Sonenshein, R. J. (1993). Politics in Black and White: Race and Power in Los Angeles Princeton: Princeton University Press.

Steele, S. (1990). White Guilt: The Content of our Character. New York: Harper Perennial. 


\section{Perry-Black Mayors in Non-Majority (Medium-Sized) Cities}

Stone, Clarence. (1989). Regime Politics. Lawrence: University of Kansas Press.

Svara, James H. (1987). "Mayoral Leadership in council-manager cities: Preconditions versus preconceptions." Journal of Politics 49: 207-227.

Svara, James H. (1990). Official Leadership in the City: Patterns of Conflict and Cooperation. New York: Oxford University Press

Svara, James H. (1994). Facilitative Leadership in Local Government: Lessons from Successful Mayors and Chairpersons. San Francisco: Jossey-Bass Publishers.

Svara, James H. (2003). "Effective mayoral leadership in councilmanager cities: Reassessing the facilitative model," National Civic Review, (July). Volume 92 Issue 2, Pages 157 - 172

Swain, Carol M. (1996). Black Faces, Black Interests: The Representation of African Americans in Congress. Cambridge: Harvard University Press.

Tate, Katherine. (1993). From Protest to Politics: The New Black Voters in American

Elections. Cambridge: Harvard University Press.

Tate, Katherine. (2004). Black Faces in the Mirror: African Americans and Their Representatives in the U.S. Congress. Princeton: Princeton University Press.

Thompson, J. Philip. (2006). Double Trouble. Cambridge: Oxford University Press.

West, Cornel. (1993), Race Matters. New York: Vintage Books

Wilkins, Roger. (1989). "The Black Poor are Different." New York Times, August 22, p. A23. 
Williams, Melissa S. (1998). Voice, Trust, and Democracy: Marginalized Groups in

the Failings of Liberal Representation. Princeton: Princeton University

Press.

Wilson, James Q. (1980). Reprinted. Negro Politics: The Search for Leadership. New York: Octagon Books.

Wilson, William Julius. (1987). The Truly Disadvantaged. Chicago, IL: University of Chicago Press.

Wilson, William Julius. (1990). "Race-Neutral Policies and the Democratic Coalition" The American Prospect, March 21.

Wilson, William Julius. (1991). "Public Policy Research and the Truly Disadvantaged." In The Urban Underclass, eds. Christopher Jencks and Paul E. Peterson. Washington D.C.: The Brookings Institution.

Wilson, William Julius. (1996). When Work Disappears. New York: Vintage Books.

Woody, Bette. (1982). Managing Crisis Cities: The New Black Leadership and the Politics of Resource Allocation. Westport, CT: Greenwood.

Young, Iris Marion. (1990). Justice and the Politics of Difference. Princeton, NJ: Princeton University Press. 